\title{
Christine De Pisan and Murasaki Shikibu as Medieval Feminists
}

\author{
Harika Bashpinar \\ Middle East Technical University, Turkey
}

The Middle Ages is generally considered to be the dark ages, especially in Europe. The political turmoil, the ever-going fight between emperors and the papacy, the Black Death which killed almost half of the European population, all happened in this period. From this point of view, yes, it is really dark. However, it is also this period that witnessed the beginnings of a radical change in philosophy. Through the end of it, great writers like Petrarca and Boccaccio prepared the grounds for humanism. While they are marked as the shining stars of the Middle Ages, there is also another change which is quite important, yet a little unnoticed when compared to the dominant belief patterns of the period. This development in question is the emergence of women writers and their calling attention to the position of women in society. Therefore, it can be asserted that besides humanism, the foundations of feminism was also laid in the Middle Ages.

While in Europe women writers like Christine de Pizan and Marie de France appeared and questioned the plight of women, in a faraway country, in Japan, another women writer was questioning the same problem and depicting the sufferings of women. Murasaki Shikibu, with her masterpiece The Tale of Genji, became one of the milestones in world literature, and in recent years in feminist literature. Thus, to make a complete picture of the birth of feminism, one should not limit the scope of works only to those of European writers. An analysis which focuses on writers from both the west and the east will show that medieval women were subject to more or less the same problems in these different parts of the world. It also reveals that this problem was noticed, questioned, and made the focus of literature both in Europe and in the East. Therefore, the aim of this study is to reveal the parallels regarding the question of women in Medieval Europe and Heian Japan, and also in the works of Christine de Pizan and Murasaki Shikibu. 


\section{Christine de Pizan}

Known as the first professional woman writer, Christine de Pizan was born in Venice in 1364. When her father was invited by Charles V of France, as a child, she moved to the court, where she had the opportunity to learn how to read and write and then to study rhetoric and philosophy. She was uncommonly lucky for the education she got, since medieval women were deprived of such education which was mainly provided for men. She was also lucky in that she had a happy marriage, and her husband encouraged and helped her to increase her knowledge, which would provide her with the necessary background to become a writer in the following years.

After the death of her husband when she was still very young, she had to take care of her children, and this responsibility led her to become a professional writer. What is distinguished about this period in Christine's life is that she may have chosen to get married again. Yet, she proved a woman's ability of self-governance by standing alone in a patriarchal society and providing for her family on her own. She started her career with writing lyric verse. However, her reputation was mainly brought by her later writings on politics, moral issues, and the condition of women in society. Her talent in writing, and especially her courage to protest the traditional position of women made her one of the most remarkable literary figures in the Middle Ages.

She was deeply concerned with the anti-feminism of her time, which showed itself in her letters criticizing the misogyny in the Roman de la Rose. Her exchange of letters on this issue later became known as the Debate of the Romance of the Rose. What irritated her most was Jean de Meun's misogynist representation of women as frivolous, untrustworthy, and immoral beings. Probably as an answer to the misogynist tradition of her culture, she wrote The Book of the City of Ladies. Inspired by Boccaccio's De Mulieribus Claris, the book relates stories of several powerful women from history and mythology in order to show that women actually have the same traits of power, intelligence and virtue as men. The city she builds is a kind of utopian world through which she creates 'a room of women's own'.

Although Christine de Pizan seems to accept the roles attributed to women by the patriarchal tradition, she presented some radical ideas about the education and equality of women, which was out of question in those years. She expressed her belief in women's potential to be equal to men in intellectual terms. That is why The Book of the City of Ladies is a masterpiece of feminist writing. 


\section{Murasaki Shikibu}

One of the greatest Japanese authors, Murasaki Shikibu lived in the Heian Period and wrote The Tale of Genji, highy appreciated as the world's first novel. Very few details are known about Lady Murasaki Shikibu's life, and these are mostly from her diary. Like Christine de Pizan, she was a daughter of a court scholar. Having eagerly listened to and absorbed the literary pieces her father taught to her brother, she was equipped with a great knowledge of various subjects and of Chinese, the official language as Latin was in Europe, which was mastered only by men. After she was widowed, she started writing The Tale of Genji, which she is believed to have continued to work on until she died.

Both from her diary and from the world she pictures in The Tale of Genji, it is understood that women were deprived of any kind of authority and even of their real names. As Lady Murasaki Shikibu's pen name suggests, she takes Murasaki from the name of the character in The Tale of Genji, and Shikibu from his father's rank. Then, it is not a surprise that women, who were not granted even real names, were prisoned in the household with no authority over their lives. In such a situation very similar to that of Europe, Shikibu was concerned with the sufferings of women and reflected this in The Tale of Genji. One can even argue that the hero of the novel is its women, not the Shining Genji, since the writer's main concern is the feelings of the novel's female characters. Therefore, in recent years, Genji has been considered as a novel about women, and Lady Murasaki Shikibu has been granted the position among the first feminist writers.

Naturally, as a writer working for the court, she is not expected to have overtly thrown feminist arguments in her works. One can understand that she must have written cautiously in order not to lose her position in the court. Nevertheless, a careful reading of both Shikibu's life style and of The Tale of Genji will easily reveal that she was not contended with the limited opportunities there were for women. With her choices in life and her treatment of characters in her novel, Shikibu is worthy of the same reputation Christine de Pizan in Europe was given, since both women had similar life styles, and as writers, both expressed their interest in the plight of their own sex. 


\section{A Comparative Analysis}

Before getting involved in the comparison of the writings of Christine de Pizan and Murasaki Shikibu, it would be illuminating to make a more detailed review of their life styles and experiences so that the similar aspects of these women's characters become clear and explain the background of their feminist ideas. To start with, both writers were able to acquire a kind of education which was not allowed to women in their time. As stated before, Christine de Pizan was lucky, since both her father and husband were helpful, and they did not oppose to her education. Murasaki Shikibu, on the other hand, got her education in a different, indirect way, because her father did not support the idea that women can and should learn the same things as men do. We learn that from Shikibu's diary:

When my brother, Secretary at the Ministry of Ceremonial, was a young boy learning the Chinese classics, I was in the habit of listening with him and I became unusually proficient at understanding those passages that he found too difficult to grasp and memorize. Father, a most learned man, was always regretting the fact: 'Just my luck!' he would say. 'What a pity she was not born a man!' (The Diary of Lady Murasaki 58).

Since the study of Chinese was appropriate only for boys, she explains, there were soon rumours about her learning. Therefore, she had to keep it secret: "Still I kept on hearing these remarks; so in the end, worried what people would think if they heard such rumours, I pretended to be incapable of reading even the inscriptions on the screens" (58). All in all, both Christine de Pizan and Murasaki Shikibu managed to learn what only men could in their culture, and this education paved the way for their writing careers and for their distinctive ideas.

Another parallel between their life experiences is the fact that both lost their husbands in a young age. However, both women proved to be strong enough not to get married again. Doing without a husband, on the contrary, set them free and provided the opportunity to be able to become full time writers. Christine de Pizan expresses this feeling of freedom and power as follows:

I felt myself completely transformed. I felt my limbs to be strongerthan before, and the great pain and lamentation which had earlier dominated me, I felt to be somewhat lessened. Then I touched myself all over my body, like one completely bewildered. ... Then I felt myself much lighter than usual and I felt that my flesh 
was changed and strengthened, and my voice much lowered, and my body harder and faster. ... Thus I became a true man (this is no fable) ... (Pizan 3).

The metaphor of becoming a man is the sign of her power to stand alone, of her non-conformity to patriarchy. That way, she decides not to marry again, because marriage does not make life easier. As she argues, it is a burden for women:

Since there is so much hardship for women in the state of widowhood, it could seem to some people that therefore it would be better for them all if they remarried. This assumption could be countered by saying that if in married life everything were all repose and peace, truly it would seem sensible for a woman to enter it again, but because one sees quite the contrary, any woman ought to be very wary of remarriage (qtd. in Nowacka 83).

Lady Murasaki Shikibu did the same by not getting married again, because becoming a widow was a kind of liberation for her to write freely. In both societies, Europe and Japan, women had only two choices in life, marriage or cloister. However, these two women did something no one did, and became writers, in a way created a third alternative for themselves. This shows that they were strong in character and had the spirit to raise questions about the hardships of womanhood.

Considering the lives and personal traits of these writers, one can expect to find similar concerns in their writings. To start with, Christine de Pizan's The Book of the City of Ladies can be considered as a feminist manifesto of the time. Clearly seen in Jean de Meun's Roman de la Rose, misogyny was part of medieval society. Starting with Christianity, in which Eve is seen responsible for seducing Adam and for causing the fall, women has been subject to criticisms ranging from their being deceitful and immoral to their inferiority. According to her, "misogynist discourses cemented the negative essentialist objectification of 'Woman' and had a pernicious effect on the male reader, for it encouraged the mistreatment of actual women" (Nowacka 9). Therefore, there must be somebody to talk back to these misogynist writings, and Christine de Pizan was astonished to find that previous women writers had put up with accusations (Pizan 243). Thus, she becomes the one to defend her sex.

What she emphasizes most is the equality of the sexes. She believes that if women were given the same opportunities and the same education, they would easily 
compete with men in both intellectual and artistic terms. As she writes, "If it were the custom to send little girls to school and teach them all sorts of different subjects there, as one does with little boys, they would grasp and learn the difficulties of all the arts and sciences just as easily as the boys" (qtd. in Nowacka 82). In other words, the source of sexual inequality is not that women are inferior, but the fact that they lack the necessary education. Also, the physical power which is lacking in women, she says, does not mean that they are intellectually inferior. The key, in her opinion, is education, since it can be "directed to their 'cultivation', the inculcation of virtue and their moral education: in other words, to assist them to achieve the fullest potential of their gender - as a 'charming' lady in the court, as a wife and as a mother" (91).

Besides arguing for the equality and education of women, Christine de Pizan also makes a criticism of the men who cannot be satisfied with one woman and keep on chasing others:

I respond to them that those who wrote this down in their books did not, I think, seek to do anything else in their lives but deceive women; these men could not get enough of them, and every day they wanted new ones, without remaining loyal, even to the most beautiful of them. What was the result for David and King Solomon? God became angry with them and punished their excess. There have been many others, and especially Ovid, who desired so many of them and then thought he could defame them (Pizan 41).

With examples from history and literature, she makes a picture of the men who lack loyalty to and respect for their wives. According to her such treatment of women results from men's lack of virtues, not from women's being insufficient or inferior. Apparently, such a man is not of any value: "Does such a man deserve to possess anything of value, a skirt chaser who adds all women to his list and then, when he is no longer capable of anything and is already an old man, thinks he can successfully cover up his shame by blaming women with his clever arguments?" (41). She grants no value to men who do not value women, that is why she advices to her son "not [to] be a deceiver of women; honor them and do not defame them. Limit yourself to loving a single one and do not quarrel with any" (43).

The City of Ladies she builds in her book provides a safe place for women which should protect them from the misogynist accusations and mistreatment of men. 
While setting the foundation of the city Reason helps women and 'throws' the foundation stone. In this scene, Wagner emphasizes that "Her wording is curious; rather than carefully situating the foundation stone, she hurls it. . . Reason's throwing is a reminder that the creation of an authentic woman's space requires force-the act of throwing" (71-2). From this statement it can be inferred that Christine de Pizan implies the necessity for women to 'throw' away the oppressive powers and create an authentic place. Thus, she encourages women to take firm steps through a feminist world of their own creation, which means that women should not expect men to change the situation. On the contrary, women themselves must initiate the movement by taking active roles.

As understood from her arguments, she is a firm advocate of women's dignity and equality. However, she is accused by some critics for her acceptance of women's traditional roles in the society and in the household. She is accused, because in The Book of the City of Ladies she gives some practical and moral instructions to women, from which it is seen that she accepts women's position in society as obedient wives who are only responsible for the management of the household and for being a good mother. Yet, when the conditions and the time in which Christine de Pizan wrote is considered, she cannot be criticized for her acceptance of hierarchical social orders. As Nowacka argues,

The source of modern 'disappointment' in Christine, then, is her acceptance of traditional social roles for women and her failure to push for greater social reform which would advance the position of women in the socio-political hierarchical structure. To a great extent, this 'disappointment' is an anachronistic misreading of both the Trésor and the Cité. For, although Christine does not advocate radical social reform, this does not signify that she was not interested in improving the condition of women in her time (89).

All in all, Christine de Pizan clearly and courageously fights for the elimination of the misogynist accusations on women and always pushes forward, through feminism, which makes her a key figure in feminist literature.

Lady Murasaki Shikibu, as stated above, shares much of Christine's ideas and reflects them in her book. As a novel, The Tale of Genji at first seems much different from The Book of the City of Ladies. However, the writer's concern for the oppression and sufferings of women is an undisputable parallel between them. 
To begin with, Murasaki Shikibu vividly pictures the constrains of patriarchal society in the novel. Women in Heian Japan are house-bound. For political reasons they are used by their fathers, which leads to arranged marriages. It is also a striking fact for the period's society that women hardly see any men other than their fathers and husbands throughout their lives. They are prisoned behind the blinds and as Shikibu writes in her diary, they "try to make themselves as invisible as possible" (52). It is also a polygamous society, which is so cruel that men are allowed to take as many women as they wish, and women, on the other hand are not allowed even to be jealous. When they get married, they are expected to look after their husbands and to be patient, to put up with everything. Shikibu displays this culture in the Bloom Tree chapter of the tale, in which men make assertions like "A wife's main duty is to look after her husband" and "One should settle on someone wholly dependable, quiet, and steady" (Shikibu 25).

As men see women much inferior to themselves, they are generally of the opinion that "It is probably not a bad idea to take a wholly childlike, tractable wife and form her yourself as well as you can" (25). This is why Genji takes her concubine Murasaki when she is only ten years old. He abducts the girl to shape her according to his desires. Another reason why he chooses to take her is that

She does not talk back. He has seen her accept a scolding with downcast gaze and gathered that she would accept his own guidance meekly. He therefore dreams of making her his. "How he would love to have her with him," the narrator says, "and bring her up as he pleased!" (Tyler 22).

Just as Genji takes Murasaki without her consent, he also makes love to her, again, without having the girl's consent.

He had not seriously thought of her as a wife. Now he could not restrain himself. It would be a shock, of course.

What had happened? Her women had no way of knowing when the line had been crossed. One morning Genji was up early and Murasaki stayed on and on in bed...

... She had not dreamed he had anything of the sort on his mind. What a fool she had been, to repose her whole confidence in so gross and unscrupulous a man (147). 
Definitely, this first intercourse remains in Murasaki's mind as a horrible event. The feminist critic Komashaku even calls this event as rape from Murasaki's perspective (Tyler 23). It shows how humiliating men's action can be for women. Still, men do not pay attention to their feelings.

It is obvious that while the society grants men all kinds of freedom, it confines women within walls and blinds. Once they are married, they must continue being an obedient wife. The only alternative is going into a nunnery, but this also requires the permission of the husband. Murasaki, deeply hurt first by the 'rape' and then by Genji's constantly going to his other women, wishes to go into a convent so that she can get rid of the male oppression. However, no matter how many times she asks Genji to let her go, each time he selfishly refuses her wish:

"But that cannot be. What would my life mean without you? Not much has happened all these years, but all I ask is the joy of our being together morning and night. Do see my extraordinary affection for you through to the end."

He said no more, which hurt her, since she had heard that much before (448).

While Murasaki Shikibu shows the sufferings of women, she also makes her female characters find ways to resist men. Murasaki, for example, seems to have no choice other than putting up with Genji, because he does not let her become a nun. However, she is a strong women, who in her own way expresses her nonacceptance of this life style. According to Tyler, there are three moments in the novel when Murasaki makes a self-affirmation, which is not regarded proper to a lady at that time. These moments are when Murasaki makes a firm response for Genji's other women by saying "Well, I am I!" (Tyler 18), when she resists to Genji by saying "Familiarity often breeds contempt" and turns her back to him (33), and finally when she is in her death bed, yet does not want the housemaids to call for Genji (53), which is an affirmation of the fact that Murasaki does not desperately need Genji, she does not give in to him. With such moments of resistance, Murasaki becomes an independent, distinct individual as possible as in her conditions.

Another character Shikibu grants the awareness of male oppression is the Third Princess. She is aware of the fact that marriage does not prove to be good for women. So, she endeavours to discourage men from being attracted to her by "denying her adult sexual role" (Henitiuk 195). She pretends to be childish by behaving in an infantile manner. She actually managespostponing to enter the adult 
woman's world for some time, since she is described as "really so very innocent and inexperienced" (442). It is also seen that she rejects her suitors. However, she does not reject them because they do not appeal to her. She simply rejects all men, since she knows that getting into relationship with men means misery and oppression. In Henitiuk's words, the Third Princess' infantile manners are an example of female incompetence, "Yet the unprecedented level of incompetence displayed here can be interpreted as a self-defence strategy consciously or even unconsciously employed by someone who, recognizing her own impotence to make a place for herself in a frequently hostile world, withdraws from the game" (199). This way she creates a room for herself into which male cannot enter. Thus, she becomes independent and devoid of male oppression.

As this short analysis of the works of Christine de Pizan and Murasaki Shikibu shows, the cultures of Medieval Europe and Heian Japan differed from each other, and women in such different parts of the world shared more or less the same feelings of imprisonment and oppression. While in Europe women were seen as the source of evil and the seducer of men, in Japan they were the objects of male desire. However differently, both cultures limited women's life to the household and within the borders of patriarchy. European men were encouraged to sexually avoid and also to tyrannize women. In Japan, on the other hand, they were free to sexually exploit women according to their desires.

Both The Book of the City of Ladies and The Tale of Genji present several details of male exploitation, and at the same time put forward the authors' ideas and criticisms. Personal experiences of both writers supports the idea that education helps women to achieve the fullest potential of their gender, therefore, they depicted in their works female characters who are fully aware of their condition and also their potential, and try to be independent as much as possible. In other words, both Christine de Pizan and Murasaki Shikibu "anticipated the feminist necessity of Virginia Woolf's 'room of one's own"” (Wagner 69), which is in a way achieved in the City of Ladies, and also, though slightly, in the lives of Shikibu's female characters. In conclusion, Christine de Pizan and Murasaki Shikibu are important figures in feminist literature, and in my opinion Murasaki Shikibu is worthy of the same reputation Christine de Pizan has among medieval writers. 


\title{
References and notes:
}

Henitiuk, Valerie. "Seeking Refuge in Prepubescent Space: The Strategy of Resistance Employed by The Tale of Genji's Third Princess". Canadian Review of Comparative Literature. 28.2 (2001): 193-214.

Nowacka, Keiko. "Reflections on Christine de Pizan's 'Feminism'. Australian Feminist Studies 17.37 (2002): 81-97.

Pizan, Christine de. Debate of the "Romance of the rose". Chicago: University of Chicago Press, 2010.

Shikibu, Murasaki. The Tale of Genji. New York: Penguin Group, 2001.

---. The Diary of Murasaki Shikibu. New York: Penguin Group, 1996.

Tyler, Royall. The Disaster of the Third Princess: Essays on the Tale of Genji. Canberra: ANU E Press, 2009.

Wagner, Jill E. "Christine de Pizan's City of Ladies: A Monumental (Re)construction of, by, and for Women of All Time”. MFF. 44.1 (2008): 69-80.

\section{Summary}

\section{Christine De Pisan and Murasaki Shikibu as Medieval Feminists}

\author{
Harika Bashpinar \\ Middle East Technical University, Turkey
}

This study presents a comparative reading of Christine de Pizan'sThe Book of the City of Ladies and MurasakiShikibu's The Tale of Genji. Having lived and written in the Middle Ages, both Christine de Pizan and MurasakiShikibu share the privilege of being among the first women writers as well as the first feminists. As their life stories picture them as strong, independent women unusual at that time, their works elaborate on the plight of their sex in a patriarchal and oppressive society, and propose ways to transcend these borders. What is striking in such a reading is that it makes the modern reader see that oppression on women has been existent since at least the Medieval Era, and it has been a case throughout the world. Since neither Pizan nor Shikibuknew the culture and works of the other, their attracting attention to the same issues suggests an interesting reading.

Key words: The Book of the City of Ladies, the Tale of Genji, medieval, feminism, misogyny 